\title{
Jaundice in the Newborn at the Teaching Hospital of Brazzaville
}

\section{Gaston Ekouya Bowassa ${ }^{1,2 *}$, Giresse Tsouassa Wa Ngono ${ }^{2}$, Neli Yvette Ngakengni1,2, Engoba Moyen1, Koumou Onanga ${ }^{1,3}$, Steve Missambou Mandilou ${ }^{2}$, Georges Moyen ${ }^{1}$}

\author{
${ }^{1}$ Faculty of Health Sciences, Marien NGOUABI University of Brazzaville, Brazzaville, Congo \\ ${ }^{2}$ Department of Neonatology, University Hospital of Brazzaville, Brazzaville, Congo \\ ${ }^{3}$ Department of Biochimy, University Hospital of Brazzaville, Brazzaville, Congo \\ Email: *ekouyabg@yahoo.fr
}

How to cite this paper: Ekouya Bowassa, G., Tsouassa Wa Ngono, G., Ngakengni, N.Y., Moyen, E., Onanga, K., Missambou Mandilou, S. and Moyen, G. (2019) Jaundice in the Newborn at the Teaching Hospital of Brazzaville. Open Journal of Pediatrics, 9, 111-118.

https://doi.org/10.4236/ojped.2019.92011

Received: March 5, 2019

Accepted: May 5, 2019

Published: May 8, 2019

Copyright $\odot 2019$ by author(s) and Scientific Research Publishing Inc. This work is licensed under the Creative Commons Attribution International License (CC BY 4.0).

http://creativecommons.org/licenses/by/4.0/

\begin{abstract}
Introduction: Jaundice is a major symptom during neonatal time. It is defined by a bilirubin $\geq 50 \mathrm{mg} / \mathrm{l}$. Objectives: To determine the frequency of neonatal jaundice at the Brazzaville University Hospital, to determine the main etiologies, to evaluate the management, to specify the evolution. Patients and Method: It was a prospective and descriptive study that was conducted in the Neonatology Department and Biochemistry Laboratory of the University Hospital of Brazzaville, from $1^{\text {st }}$ August 2015 to $31^{\text {st }}$ July 2016. It included newborn children admitted into the neonatal unit for treatment of jaundice. The variables studied were epidemiological, clinical, etiological therapy and outcome. Results: The frequency of the neonatal jaundice is $7.2 \%$. The hyperbilirubinemia as not conjugated was found in $99.1 \%$ of cases. The main causes are bacterial neonatal infection $\mathrm{n}=102(47.9 \%)$, the physiological icterus $n=46(21.6 \%)$ and the $A B O$ incompatibility $n=40(18.8 \%)$. The treatment consists of the phototherapy in all cases. Each phototherapy session lasts 3 hours $\mathrm{n}=99(56.9 \%), 6$ hours $\mathrm{n}=58(33.3 \%)$ and 12 hours $\mathrm{n}=$ 17 (9.8\%). The average duration of the administering of the therapy is of $3 \pm 2$ days. Hyperbilirubinemia encephalopathy occurred in 62 (29.1\%) cases, including 49 cases of kernicterus. The death occurred in 70 (32.9\%) children. Conclusion: The importance and the gravity of the neonatal jaundice require primary preventive means based on proper care in pregnancy and the birth. While the secondary prevention includes high index of suspicion, comprehensive diagnostic equipment availability to prevent acute bilirubin encephalopathy.
\end{abstract}

\section{Keywords}

Jaundice, Neonatal, Phototherapy, Bilirubin Encephalopathy 


\section{Introduction}

Jaundice is a common symptom in the neonatal period [1]. Globally, it affects $84 \%$ of term newborns [1].

In the United States and France, jaundice is a common occurrence and affects respectively $65 \%-85 \%$ and $50 \%-70 \%$ of newborns whose gestational age is greater than or equal to thirty-five weeks of amenorrhea [2] [3]. In Africa, according to hospital statistics, jaundice accounts for $14.6 \%$ of hospitalization cases in Nigeria [4].

The relatively high frequency of jaundice during the neonatal period is related to the physiological peculiarities of the newborn which may be due to polycythemia, hyperhaemolysis and hepatic immaturity [5] [6] [7].

Complications, particularly neurological complications, are responsible for death and serious sequelae in the absence of adequate care.

In Congo, no study has been conducted to this major neonatal clinic condition. Also, this study is carried out with the aim of improving the management of jaundice in the neonatology department of the Brazzaville University Hospital. The specific objectives are to:

- determine the frequency of neonatal jaundice;

- determine the main etiologies;

- evaluate the management;

- specify the evolution.

\section{Material and Methods}

It was a prospective, descriptive and analytical study, carried out in the Neonatology Department and Biochemistry Laboratory of the University Hospital of Brazzaville, from $1^{\text {st }}$ August 2015 to $31^{\text {st }}$ July 2016 (12 months). It involved all neonates hospitalized for jaundice in the Neonatal department during the study period with total bilirubinemia $\geq 50 \mathrm{mg} / \mathrm{l}$ after parental consent for participation in the study.

Neonates with clinically jaundice, for whom no total bilirubinemia assay was performed, and those whose parents did not consent to participate in the study, were not included. On these criteria, 213 newborns were selected.

The determination of total and conjugated plasma bilirubinemia was performed by the Erba Mannheim XL Syspack ${ }^{\circledast}$.

The variables studied were:

- in relation to the characteristics of the parents:

- age;

- the blood group;

- in relation to the obstetrical history of the mother:

- the gestation;

- parity;

- the evidence of blood transfusion during pregnancy;

- the search for irregular agglutinins; 
- relating to the siblings:

- the existence of jaundice in the neonatal period;

- the existence of a G6PD deficiency

- in relation to childbirth and birth:

- the mode of delivery;

- the term;

- anthropometric parameters;

- concerning newborns:

- age;

- sex;

- the characteristics of jaundice;

- the biological aspects:

- total bilirubinemia;

- the values of hemogram;

- the diagnosis;

- therapeutic outline;

- evolution.

The data collected on the proform sheet were entered on the EPI Data version 3.1 software and analyzed on the EPI Info version 7 software. The quantitative variables were expressed as means \pm standard deviation and the qualitative variables by their absolute frequency. For comparisons, we used the Chi-square test for qualitative variables and the Variance Analysis Test (ANOVA) for quantitative variables. The threshold of significance was set at $\mathrm{p}<0.05$.

\section{Results}

During the study period, 2958 newborns were hospitalized, of which 213 for jaundice or $7.2 \%$ of admissions.

The average age of parents was $33.5 \pm 7.9$ years (range: 18 and 58 years) for fathers and $26.3 \pm 6.5$ years (range: 14 and 42 years) for mothers.

The blood group was respectively for the father and the mother: O: $n=98$ (46\%) and $\mathrm{n}=103$ (48.4\%); $\mathrm{A}: \mathrm{n}=71$ (33.3\%) and $\mathrm{n}=65(30.5 \%) ; \mathrm{B}: \mathrm{n}=44$ $(20.7 \%)$ and $n=40$ (18.8\%); $A B$ : only in mothers, $n=5(2.3 \%)$. Discordant couples in the ABO group were 73 (34.3\%).

Regarding the Rhesus group, it was respectively for the father and the mother, positive in 208 (97.7\%) and 204 (95.8\%) of the cases. There was a discrepancy in the Rh group of parents in 11 (5.2\%) cases.

Mothers were primigravida in $86(40.4 \%)$ cases, multi-gravida in $76(35.7 \%)$ and large multi-gravida in $51(23.9 \%)$ cases. They were primiparous in 126 (59.2\%) cases, multiparous in $71(33.3 \%)$ cases and grand-multiparous in 16 (7.5\%) cases.

During pregnancy, no search for irregular agglutinin and no blood transfusions were performed.

A history of jaundice and anemia in the neonatal period in siblings was found in $4(1.9 \%)$ cases and $1(0.5 \%)$ cases, respectively. No case of G6PD deficiency 
was noted in the siblings.

Delivery was vaginal in $185(86.9 \%)$ cases and by caesarean section in 28 (13.1\%).

By sex, newborns were: male: $\mathrm{n}=121$ (58.8\%); female: $\mathrm{n}=92(43.2 \%)$.

The mean birth weight was $2456.8 \pm 741.1 \mathrm{~g}$ (range 1000 to $4000 \mathrm{~g}$ ). Newborns had low birth weight in 114 (53.5\%) cases. The average size was $46.5 \pm 4.5 \mathrm{~cm}$ (extremes: 28 and $55 \mathrm{~cm}$ ). The average of head circumferences was $30.5 \pm 2.8 \mathrm{~cm}$ (25 and $37 \mathrm{~cm}$ ).

The mean age of the newborns at admission was $58.9 \pm 102.1$ hours (range: one hour and 26 days). Newborns were premature in 97 (45.5\%) cases.

Jaundice was onset: early before the 72nd hour of life in 96 (45.1\%) cases; intermediate, occurring between the 3rd and 7th day of life: 105 (49.3\%); late after the 7th day: 12 (3.6\%). Stools were normal staining for 206 (96.7\%) and discolored in 7 (3.3\%) cases. Jaundice with free bilirubin in 211 (99.1\%) cases and bilirubin conjugates in $2(0.9 \%)$ cases.

Mean total bilirubin was $184.6 \pm 81.9 \mathrm{mg} / \mathrm{l}$ (range: 53.2 to $467 \mathrm{mg} / \mathrm{l}$ ).

The diagnosis was: neonatal infection in $102(47.9 \%)$ cases, physiological jaundice 46 (21.6\%) cases, incompatibility ABO 40 (18.8\%) cases, incompatibility Rhesus 4 (1.9\%), mother's milk jaundice 4 (1.9\%), other causes 8 (3.7\%), cause not determined $9(4.2 \%)$.

Phototherapy was used in 174 (81.7\%) neonates. No newborn have benefited from exchange blood transfusion.

This was conventional discontinuous phototherapy in all cases. It was administered in 3-hour sessions in 99 (56.9\%) newborns, 6-hour sessions for 58 (33.3\%) and 12 hours for 17 (9.8\%). The average total duration of phototherapy was $3 \pm 2$ days (range: 1 to 9 days).

The average decrease in bilirubin was $1.1 \%$ after 24 hours in neonates treated with phototherapy. The decrease in bilirubin levels after 24 hours averages $6 \%$ in 3 -hour sessions, $12.3 \%$ in 6 -hour sessions and $16 \%$ in 12 -hour sessions. The kinetics of the evolution of bilirubinemia in neonates treated with phototherapy is mentioned in Figure 1 and Figure 2.

Adverse effects of phototherapy were noted in 37/174 (21.3\%) neonates. These were: dehydration: 30 (81.1\%) cases; hyperthermia: 5 cases; intestinal obstruction: 2 cases.

Acute bilirubin encephalopathy occurred in 62 (29.1\%) cases, including 49 cases of kernicterus.

The death occurred in 70 (32.9\%) children.

\section{Discussion}

The frequency of neonatal jaundice estimated at $7.2 \%$ in this study is significant, compared to the results of the Kabamba Mutombo study [8] in the Democratic Republic of Congo which noted a hospital frequency of $4.2 \%$. Rabesandratana [9] in Madagascar, in a study on the epidemiological and clinical aspects of medical emergencies in neonatology in Mahajanga reports a frequency of 3.7\%. 


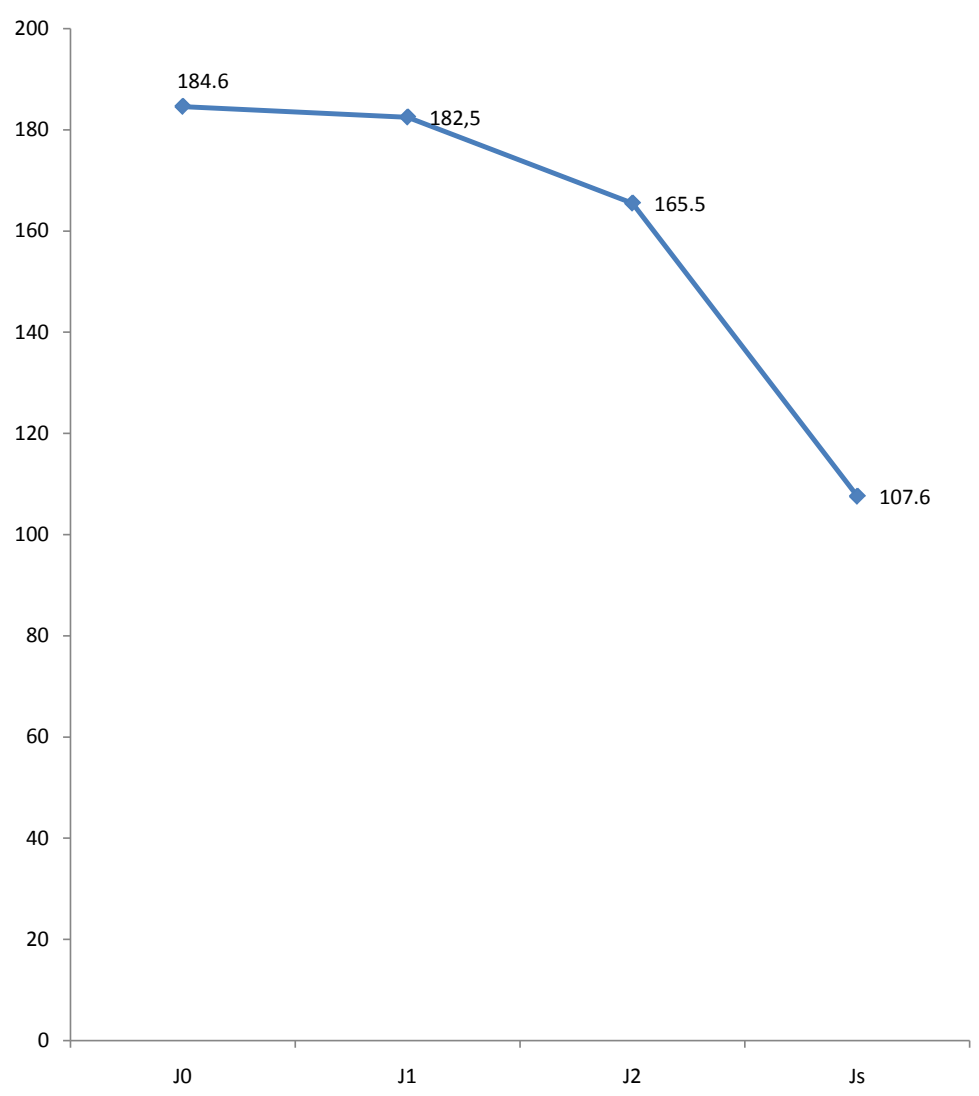

Figure 1. Change in bilirubin means (mg/l) before phototherapy, 24 to 48 hours after phototherapy and at discharge.

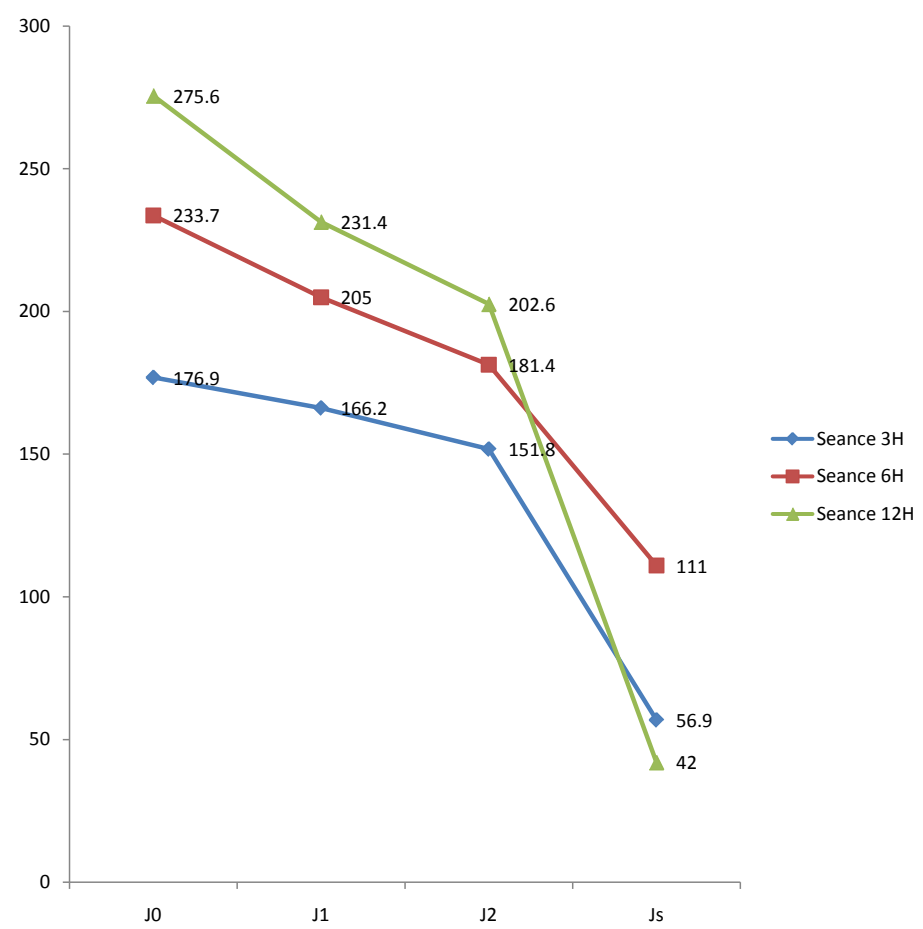

Figure 2. Changes in the mean total bilirubin level before phototherapy, 24 to 48 hours after the phototherapy, and on discharge depending on the duration of the sessions. 
The frequencies reported in our work as well as those of Kabamba Mutombo [8] and Rabesandratana [9] are low compared to data from the Nigerian authors [4] [10], who report respectively $14.6 \%$ and $32 \%$.

Methodological differences may explain these disparities. Indeed, the types of studies, the samples, the periods and the inclusion criteria are the same in these studies.

In our study, the population of neonates with unconjugated hyperbilirubinemia was $99.1 \%$. The prevalence of unconjugated hyperbilirubinemia in the neonatal period is known because reported by all the authors consulted [2] [8] [9] [10] [11] [12], although in different proportions.

Neonatal bacterial infection (48.3\%), physiological jaundice $(21.8 \%)$ and incompatibility mother-infant in the ABO system (19\%) are the main causes of jaundice of the newborn. For Kabamba Mutombo [8], the first two causes are neonatal infection and incompatibility in the $\mathrm{ABO}$ system.

In this study, as in the work of Chime [10] in Nigeria, Kabamba Mutombo [8] in the DRC, and Koosha [13] in Iran, the frequency of neonatal jaundice due rhesus iso-immunization were noted in $3.7 \%, 1.7 \%$ and $2.1 \%$ respectively.

Other causes of jaundice such as G6PD deficiency and pyruvate kinase deficiency, reported by Sgro [12], Chime [10], Koosha [13] and Christensen [11], were not identified due to lack of appropriate equipment in our health facility.

In $4.3 \%$ of newborns, no etiology was found. This is a known fact because it is also reported in the works of African authors but also in those of developed countries [10] [11] [12] [13].

Phototherapy is the main therapeutic remedy [6] [7] [14]. We used it in $81.7 \%$ of newborns. In all cases conventional phototherapy was used.

Gordon [15] in Kenya and Brouk [16] in Algeria also used first-line phototherapy. Intensive phototherapy, the effectiveness of which is proven in severe hyperbilirubinemias, not available in Brazzaville, was the most used therapeutic method by Brouk [16].

The evolution of neonatal jaundice is closely related to gestational age, cause of jaundice and function of management. The evolution was favorable in $67.1 \%$ of newborns, death was recorded in $32.9 \%$ of newborns. Kabamba Mutombo et al. [8] reported $82.3 \%$ of favorable evolution.

Among the criteria for resolving jaundice is normalization of the total bilirubin level.

We observed a reduction of bilirubinemia after 24 hours of $10.4 \%$. Kale [17] in Turkey reported $32.6 \%$, a reduction in the average level of total bilirubin after 24 hours. The lack of continuous phototherapy explains poor results of our work.

In Brazzaville, hyperbilirubinemic encephalopathy: $29.1 \%$ of cases and nuclear jaundice $23 \%$ of cases with lethality of $57.1 \%$ are the major complications of jaundice of the newborn.

In countries with modern equipment, such as Great Britain, Denmark, Cana$\mathrm{da}$, the incidence of kernicterus is 1 per 100,000 and $1 / 43,000$ [18] [19] [20]. 
Cortey in France [21] reports an upsurge in nuclear jaundice.

\section{Conclusions}

This work was carried out on 213 newborns allowing us to determine the frequency of jaundice at the University Hospital of Brazzaville, to identify the main etiologies and to outline the therapeutic modalities as well as the evolutionary aspects.

Neonatal jaundice is a reality at the University Hospital of Brazzaville; bacterial infection and foeto-maternal incompatibility in the $\mathrm{ABO}$ system are the main causes.

The course of jaundice is severe because of the high incidence of hyperbilirubinemia encephalopathy and progression to nuclear jaundice.

The lack of early detection of jaundice in maternity hospitals, poor antenatal care and robust neonatal and maternity services, characterized by an insufficient number of conventional phototherapy devices and the lack of intensive phototherapy and fiber optics explain the high observed mortality in this work.

\section{Conflicts of Interest}

The authors declare no conflicts of interest regarding the publication of this paper.

\section{References}

[1] Bhutani, V.K., Stark, A.R., et al. (2013) Predischarge Screening for Sever Neonatal Hyperbilirubinemia Identifies Infants Who Need Phototherapy. The Journal of Pediatrics, 1625, 477-482. https://doi.org/10.1016/j.jpeds.2012.08.022

[2] Wong, R.J. and Stevenson, D.K. (2015) Neonatal Hemolysis and Risk of Bilirubin-Induced Neurologic Dysfunction. Seminar in Fetal and Neonatal Medicine, 20, 26-30. https://doi.org/10.1016/j.siny.2014.12.005

[3] Renesme, L., Tourneux, P., Bedu, A., Raignoux, J., Casper, C., Cortey, A. and Truffert, P. (2014) Recommandations internationales concernant l'ictère à bilirubine libre en maternité. Que peut-on en retenir? Archives de Pédiatrie, 21, 73-74. https://doi.org/10.1016/S0929-693X(14)71467-8

[4] Pius, S., Bello, M., Mava, Y., Djossi, S. and Ambe, J.P. (2017) Prevalence of Exchange Blood Transfusion in Severe Hyperbimirubinaemia and Outcome at the University of Maiduguri Teaching Hospital Maiduguri, North-Eastern Nigeria. $\mathrm{Ni}$ gerian Journal of Paediatrics, 44, 50-55.

[5] Labrune, P. (1998) Ictèere grave du nouveau-né. Définition et prise en charge. Archives de Pédiatrie, 5, 1162-1167. https://doi.org/10.1016/S0929-693X(99)80019-0

[6] Maisels, M.J. and McDonagh, A.F. (2008) Phototherapy for Neonatal Jaundice. New England Journal of Medicine, 358, 920-928. https://doi.org/10.1056/NEJMct0708376

[7] American Academy of Pediatrics Subcommittee on Hyperbilirubinemia (2004) Management of Hyperbilirubinemia in Newborns Infants 35 or More Weeks of Gestation. Pediatrics, 114, 297-316. https://doi.org/10.1542/peds.114.1.297

[8] Kabamba Mutombo, A., Mukuku, O., Kasongo Kabulo, B., et al. (2014) Ictères pa- 
thologiques du nouveau-né à l'hôpital Bonzola de Mbuji-Mayi, République Démocratique du Congo. Pan African Medical Journal, 19, 302-310. https://doi.org/10.11604/pamj.2014.19.302.5658

[9] Rabesandratana, N., Rasaminana, N.G., Tetto Tatanke, H., Randaoharison, P. and Andrianarimanana, D. (2011) Aspect épidémio-clinique des urgences médicales en néonatalogie à Mahajanga Madagascar. Revue d'Anesthésie-Réanimation et Médecine d Urgence, 3, 27-31.

[10] Chime, H.E., Egenede, J.A. and Arute, J.E. (2011) Prevalence of Neonatal Jaundice on Central Hospital, Warri, Delta State, Nigeria. International Journal of Health Research, 4, 123-126.

[11] Christensen, R.D., Lambert, D.K., Henry, E., Eggert, L.D., Hassan Yaish, M., Scott Reading, N. and Prchal, J.T. (2013) Unexplained Extreme Hyperbilirubinemia among Neonates in a Multihospital Health Care System. Blood Cells Molecules and Disease, 50, 105-109. https://doi.org/10.1016/j.bcmd.2012.10.004

[12] Sgro, M., Campbell, D. and Shah, V. (2006) Incidence and Causes of Severe Neonatal Hyperbilirubinemia in Canada. Canadian Medical Association Journal, 175, 587-590. https://doi.org/10.1503/cmaj.060328

[13] Koosha, A. and Rafizadeh, B. (2007) Evaluation of Neonatology Indirect Hyperbilirubinemia at Zanjan Province of Iran in 2001-2003: Prevalence of Glucose-6-Phosphate Deshydrogenase Deficiency. Singapore Medical Journal, 48, 424-428.

[14] Denery, P.A., Seidman, D.S. and Stevenson, D.K. (2001) Neonatal Hyperbilirubinemia. New England Journal of Medicine, 344, 581-590.

https://doi.org/10.1056/NEJM200102223440807

[15] Gordon, A.L., English, M., Tumaini Dzombo, J., Karisa, M. and Newton, C. (2005) Neurological and Developmental Outcome of Neonatal Jaundice and Sepsis in Rural Kenya. Tropical Medicine and International Health, 10, 1114-1220. https://doi.org/10.1111/j.1365-3156.2005.01496.x

[16] Brouk, H., Refai, S., Zemouli, A., Djabri, Y., Boukartouta, N. and Ouelaa, H. (2013) Incompatibilité foto-maternelle érythrocytaire ABO: Sévérité clinique! Transfusion clinique et biologique, 20, 312. https://doi.org/10.1016/j.tracli.2013.03.070

[17] Kale, Y., Aydemir, O., Celik, U., Kavurt, S. and Isikoglu, S. (2013) Effects of Phototherapy Using Light Sources on Oxidant and Antioxidant Status of Neonates with Jaundice. Early Human Development, 89, 57-60. https://doi.org/10.1016/j.earlhumdev.2013.09.013

[18] Manning, D., Todd, P., Maxwell, M., et al. (2007) Prospective Surveillance Study of Severe Hyperbilirubinemia in the Newborn in the UK and Ireland. Archives of Disease in Childhood. Fetal and Neonatal Edition, 92, F342-F346.

https://doi.org/10.1136/adc.2006.105361

[19] Bjerre, J.V., Petersen, J.R. and Ebbesen, F. (2008) Surveillance of Extreme Hyperbilirubinemia in Denmark. A Method to Identify the Newborn Infants. Acta Paediatrica, 97, 103-104. https://doi.org/10.1111/j.1651-2227.2008.00879.x

[20] Bedu, A. (2011) Hyperbilirubinémie severe et ictères nucléaires en France en 2011. Archives de Pédiatrie, 18, 17-18. https://doi.org/10.1016/S0929-693X(11)70948-4

[21] Cortey, A. (2012) Kernicterus: The Comeback. Archives de Pédiatrie, 19, 897-899. https://doi.org/10.1016/j.arcped.2012.06.018 